\title{
Proteomics of buccal squamous cell carcinoma: The involvement of multiple pathways in tumorigenesis
}

\author{
Jia Chen ${ }^{1}$, Qing-Yu He ${ }^{2,3}$, Anthony Po-Wing Yuen ${ }^{4}$ and Jen-Fu Chiu ${ }^{1,3}$ \\ ${ }^{1}$ Institute of Molecular Biology \\ ${ }^{2}$ Department of Chemistry \\ ${ }^{3}$ Open Laboratory of Chemical Biology of the Institute of Molecular Technology for Drug \\ Discovery and Synthesis \\ ${ }^{4}$ Department of Surgery, University of Hong Kong, Hong Kong, China
}

Squamous cell carcinoma (SCC) of the buccal mucosa is an aggressive oral cancer. It mainly occurs in Central and Southeast Asia, and is closely related to the practice of tobacco smoking and betel squid chewing. The high recurrence and low survival rates of buccal SCC require our continued efforts to understand the pathogenesis of the disease for designing better therapeutic strategies. We used proteomic technology to analyze buccal SCC tissues aiming at identifying tumor-associated proteins for the utilization as biomarkers or molecular targets. With the exception of alpha B-crystallin being substantially reduced, a number of proteins were found to be significantly over-expressed in cancer tissues. These increased proteins included glycolytic enzymes, heat-shock proteins, tumor antigens, cytoskeleton proteins, enzymes involved in detoxification and anti-oxidation systems, and proteins involved in mitochondrial and intracellular signaling pathways. These extensive protein variations indicate that multiple cellular pathways were involved in the process of tumorigenesis, and suggest that multiple protein molecules should be simultaneously targeted as an effective strategy to counter the disease. $\square$ please check sentence $\mathbf{S C C}$ antigen, G protein, glutathione S-transferase, manganese superoxide dismutase, annexins, voltage-dependent anion channel, cyclophilin A, stratifin and galectin 7 are candidates for targeted proteins. The present findings also demonstrated that rich protein information can be produced by means of proteomic analysis for a better understanding of the oncogenesis and pathogenesis in a global way, which in turn is a basis for the rational designs of diagnostic and therapeutic methods.

Keywords: Biomarker / Buccal cancer / Mass spectrometry fingerprinting / Protein profile / Two-dimensional-polyacrylamide gel electrophoresis

\begin{tabular}{|lr|}
\hline Received & $23 / 12 / 03$ \\
Revised & $27 / 1 / 04$ \\
Accepted & $29 / 1 / 04$ \\
\hline
\end{tabular}

\section{Introduction}

Oral cancers represent a major health problem worldwide and are the most common forms of cancer in Central and Southeast Asia. Squamous cell carcinoma (SCC) of the tongue and the buccal mucosa is the most common type of oral cancers. Buccal SCC tends to be more aggressive than those originating in other parts of the oral cavity, with a high rate of locoregional recurrence and poor survival

Correspondence: Dr. Qing-Yu He, Department of Chemistry, University of Hong Kong, Pokfulam, Hong Kong, China E-mail: qyhe@hku.hk

Fax: +852-2817-1006

Abbreviations: CyP-A, cyclophilin A; HSP, heat shock protein; MnSOD, manganese superoxide dismutase; MRP, mitochondrial ribosomal protein; SCC, squamous cell carcinoma; VDAC, voltage-dependent anion channel
[1]. Epidemiologic studies suggested that the incidence of oral SCCs is closely related to the practice of tobacco smoking together with nut, lime and betel squid chewing [2]. The major constituents of tobacco and betel squid are believed to cause inflammation and DNA damage, which may lead to malignant transformation. Traditionally, the treatment of oral SCC consisted of surgery, combined with postoperative radiotherapy and chemotherapy. Research data suggested that early surgical intervention and withdrawal from oral habits are beneficial to patient survival [3]. With present clinical assessment and treatment methods, patients are often diagnosed at late stages and the survival rate has not improved substantially. This highlights the necessity for continued efforts to discover suitable biomarkers for early diagnosis of the disease, and to understand its pathogenesis as a first step in improving methods of treatment.

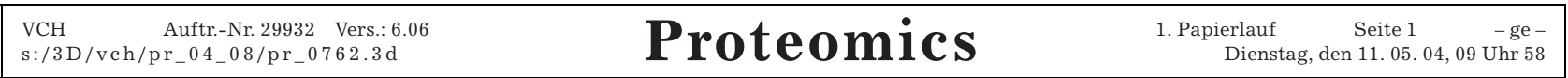


We have recently identified tumor-associated proteins in oral SCCs by means of proteomic technology. These tumor-associated proteins can be further evaluated as potential biomarkers for clinical diagnosis and as targeted proteins for pathogenetic investigations. Following proteomic analysis of tongue SCC [4], the present study focuses on proteomic variations in buccal SCC. Tumorigenesis involves multiple pathological transformations, leading to the alterations of proteins that play functional roles in the process. Proteomic alterations should therefore, hold detailed information regarding the biology of the disease. Our current findings demonstrated the involvements of multiple pathways in buccal SCC, with a number of tumor-related proteins showing changes in their expressions. The discovery of these potential biomarkers and molecular targets for cancer diagnostics and therapeutics has the potential to significantly change the clinical approach and outcome of the disease.

\section{Materials and methods}

\subsection{Tissue and sample preparation}

Ten pairs of surgical specimens of primary SCC of buccal mucosa and adjacent normal mucosa were collected from Queen Mary Hospital (University of Hong Kong) Hong Kong, China and stored in a deep freezer $\left(-80^{\circ} \mathrm{C}\right)$ until use. The study was approved by the University's ethics committee. All patients gave their consent in writing for the donation of tissue and blood for research purposes. The study included five male and five female patients, whose ages ranged from 53 to 81 years. The AJCC pathologic stages were 2 T1, 5 T2, and 3 T3. Table 1 lists detailed histological data for the tissue samples used. Fig. 1 provides a representative histological picture showing a pair of matched tissue samples side by side. Overall, the tumor specimens contained $68 \pm$ $21 \%$ tumor cells. Total proteins were extracted from the tissues according to a procedure described previously [4]. The protein concentration of each sample was determined by the Bradford method and the protein samples were stored at $-80^{\circ} \mathrm{C}$ in aliquots.

\subsection{2-DE}

2-DE was carried out with Amersham Biosystems IPGphor IEF and Ettan Dalt six electrophoresis units (Amersham Biosciences, Uppsala, Sweden) by following the protocol described previously [5]. Protein samples (150 $200 \mu \mathrm{g})$ extracted from tumor center and surrounding histologically normal mucosa were applied to the 2-DE and run side by side in pairs. Electrophoresis was performed in triplicate for each sample pair to ensure reproducibility. All gels were visualized by silver-staining [5].

\subsection{Image analysis and MS peptide sequencing}

Image acquisition and analysis were performed with an ImageScanner (Amersham Biosciences) and ImageMaster 2D Elite software (Amersham Biosciences) [5]. Comparisons were made between gel images of individual tumor and control samples. Normalized volume differences were statistically calculated for all ten cases. Consistently and significantly different spots were selected for analysis with MALDI-TOF MS. Protein spots were cut out of gels in small pieces and subjected to in-gel tryptic digestion overnight [5]. Peptide mass spectra were recorded and parameters for spectra acquisition were used as stated previously [5]. In database protein matching using MS-Fit (http://prospector.ucsf.edu/), 25 ppm or better mass accuracy and MOWSE scores over 200 were obtained in most of the analyses. Duplicate or triplicate runs were performed to ensure an accurate analysis. Western blotting was performed to confirm the specificity of the identified proteins, if necessary.

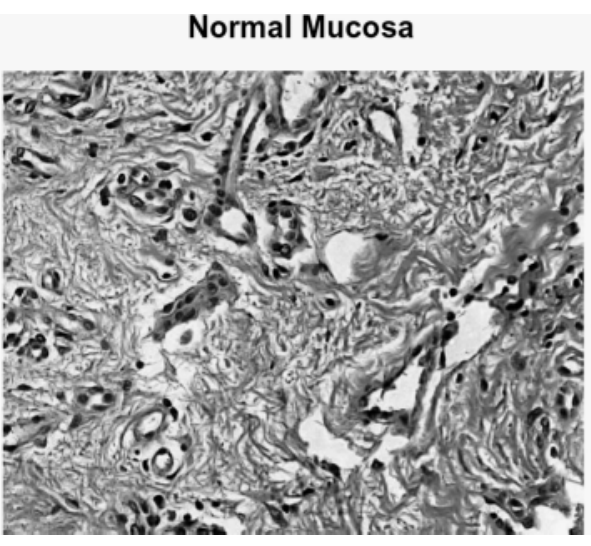

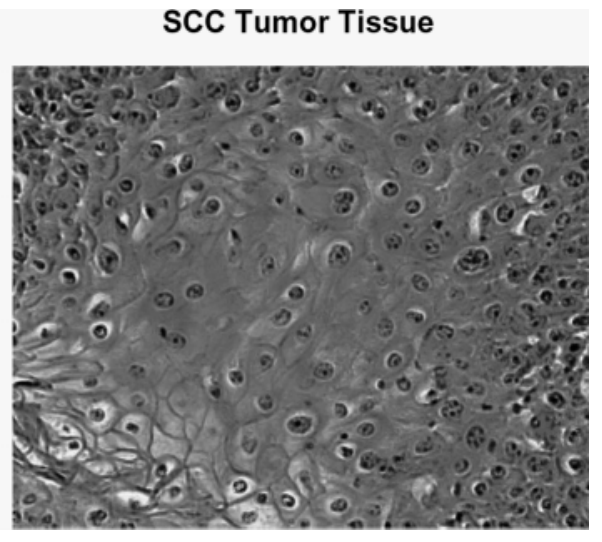

Figure 1. Representative histological picture showing a pair of matched tissue specimens side by side.

www.proteomics-journal.de 
Table 1. Patient information and histological data for the tissue samples used

\begin{tabular}{|c|c|c|c|c|c|c|c|}
\hline Patients & Sex/age & T Stage & sample pairs & $\begin{array}{l}\text { Tumor } \\
\text { cells (\%) }\end{array}$ & $\begin{array}{l}\text { Normal } \\
\text { mucosal } \\
\text { cells (\%) }\end{array}$ & $\begin{array}{l}\text { Muscle } \\
\text { cells (\%) }\end{array}$ & $\begin{array}{l}\text { Connective tissue cells } \\
\text { lymphocytes, vessel } \\
\text { cells, fibroblasts (\%) }\end{array}$ \\
\hline 1 & $M^{a)} / 80$ & T1N0M0 & $\begin{array}{l}\text { Tumor }\left(\mathrm{TC}^{\mathrm{c})}\right) \\
\text { Mucosa }\left(\mathrm{SM}^{\mathrm{d})}\right)\end{array}$ & $\begin{array}{r}95 \\
0\end{array}$ & $\begin{array}{r}0 \\
15\end{array}$ & $\begin{array}{l}5 \\
0\end{array}$ & $\begin{array}{l}20 \\
85\end{array}$ \\
\hline 2 & $\mathrm{~F}^{\mathrm{b})} / 53$ & T2NOMO & $\begin{array}{l}\text { Tumor (TC) } \\
\text { Mucosa (SM) }\end{array}$ & $\begin{array}{l}95 \\
0^{\mathrm{e})}\end{array}$ & $\begin{array}{r}0 \\
30\end{array}$ & $\begin{array}{r}0 \\
30\end{array}$ & $\begin{array}{r}5 \\
40\end{array}$ \\
\hline 3 & $F / 69$ & T3NOMO & $\begin{array}{l}\text { Tumor (TC) } \\
\text { Mucosa (SM) }\end{array}$ & $\begin{array}{r}50 \\
0\end{array}$ & $\begin{array}{l}0 \\
0\end{array}$ & $\begin{array}{l}0 \\
0\end{array}$ & $\begin{array}{r}50 \\
100\end{array}$ \\
\hline 4 & $\mathrm{~F} / 77$ & $\begin{array}{l}\text { T3N1MO } \\
\text { T2N0MO }\end{array}$ & $\begin{array}{l}\text { Tumor (TC) } \\
\text { Mucosa (SM) }\end{array}$ & $\begin{array}{r}70 \\
0 \\
75\end{array}$ & $\begin{array}{l}0 \\
5 \\
5\end{array}$ & $\begin{array}{r}0 \\
35\end{array}$ & $\begin{array}{l}30 \\
60\end{array}$ \\
\hline 6 & $\mathrm{M} / 81$ & T1NOMO & $\begin{array}{l}\text { Mucosa (SM) } \\
\text { Tumor (TC) }\end{array}$ & $\begin{array}{r}15 \\
0 \\
95\end{array}$ & $\begin{array}{r}5 \\
15 \\
0\end{array}$ & $\begin{array}{r}0 \\
70 \\
0\end{array}$ & $\begin{array}{r}20 \\
15 \\
5\end{array}$ \\
\hline 7 & $\mathrm{~F} / 74$ & T2NOMO & $\begin{array}{l}\text { Mucosa (SM) } \\
\text { Tumor (TC) }\end{array}$ & $\begin{array}{r}0 \\
70\end{array}$ & $\begin{array}{r}10 \\
0\end{array}$ & $\begin{array}{r}60 \\
0\end{array}$ & $\begin{array}{l}30 \\
30\end{array}$ \\
\hline 8 & $M / 75$ & T3NOMO & $\begin{array}{l}\text { Mucosa (SM) } \\
\text { Tumor (TC) }\end{array}$ & $\begin{array}{r}0 \\
50\end{array}$ & $\begin{array}{l}0 \\
0\end{array}$ & $\begin{array}{r}20 \\
0\end{array}$ & $\begin{array}{l}80 \\
50\end{array}$ \\
\hline 9 & $\mathrm{~F} / 72$ & T2N0MO & $\begin{array}{l}\text { Mucosa (SM) } \\
\text { Tumor (TC) }\end{array}$ & $\begin{array}{l}15 \\
50\end{array}$ & $\begin{array}{l}0 \\
0\end{array}$ & $\begin{array}{r}30 \\
5\end{array}$ & $\begin{array}{l}55 \\
45\end{array}$ \\
\hline 10 & M/62 & T2NO & $\begin{array}{l}\text { Mucosa (SM) } \\
\text { Tumor (TC) }\end{array}$ & $\begin{array}{r}0 \\
30\end{array}$ & $\begin{array}{r}20 \\
0\end{array}$ & $\begin{array}{r}0 \\
10\end{array}$ & $\begin{array}{l}80 \\
60\end{array}$ \\
\hline & & & Mucosa (SM) & 0 & 0 & 0 & 100 \\
\hline
\end{tabular}

The relative percentage (\%) of cells was rounded up to $5 \%$. Cells less than $5 \%$ were counted as 0 .

a) $M$, male

b) F, female

c) TC, tumor center

d) SM, surrounding mucosa

e) Patient has positive margin, few cancer cells are found in the adjacent submucosa of the surgical margin.

\subsection{2-D Western blotting}

Protein samples were run on 2-D gels using identical conditions as described for 2-DE in section 2.3. The separated proteins in the corresponding areas from gels were transferred onto PUDF membranes and incubated overnight at $4^{\circ} \mathrm{C}$ with a blocking buffer containing TBST (Tris-buffered saline, $0.1 \%$ Tween 20) and 5\% nonfat dry milk. Membranes were washed with TBST and incubated with monoclonal or polyclonal antibodies at a 1:500 or 1:1000 dilution for $1 \mathrm{~h}$ at room temperature or overnight at $4^{\circ} \mathrm{C}$. After washing again with TBST, the membranes were blotted with a secondary antibody conjugated with horseradish peroxidase at a 1:10000 dilution for $1 \mathrm{~h}$, and then detected by enhanced chemiluminescence (Pierce, Rockford, IL, USA) for $1 \mathrm{~min}$.

\section{Results}

Figure 2 is a typical 2D gel image for the tumor tissue of buccal SCC. More than 1200 protein spots were separated in a $13 \times 16 \mathrm{~cm}$ gel, with $M_{\mathrm{r}}$ ranging from 10 to
$200 \mathrm{kDa}$ and $\mathrm{p} /$ from 4 to 10 . Compared to the 600 protein spots detected in tongue SCC [4], significantly more proteins were observed in buccal SCC. Furthermore, the patterns of the protein profiles between these two SCCs are totally different, suggesting that different proteins and functional pathways may be involved in the two cancers. Highlighted in squares are the seven areas where significant and consistent volume differences of protein spots were found when comparisons were made between normal and tumor tissue samples. Except for one protein (alpha B-crystallin, Cryst-B) that was almost below the level of detection in tumor tissue, all other identified proteins were substantially up-regulated in SCC samples. Table 2 lists the proteins identified after in-gel digestion, MALDI-TOF MS measurement and database searching. Most of the matched peptide fingerprints had reasonable sequence coverage, precise mass accuracy $(<25 \mathrm{ppm})$ and high MOWSE scores $(>200)$. The majority of the identified proteins are intact molecules after electrophoresis! Only three spots belong to cleaved or truncated polypeptides as they appeared in areas of the 2-D 


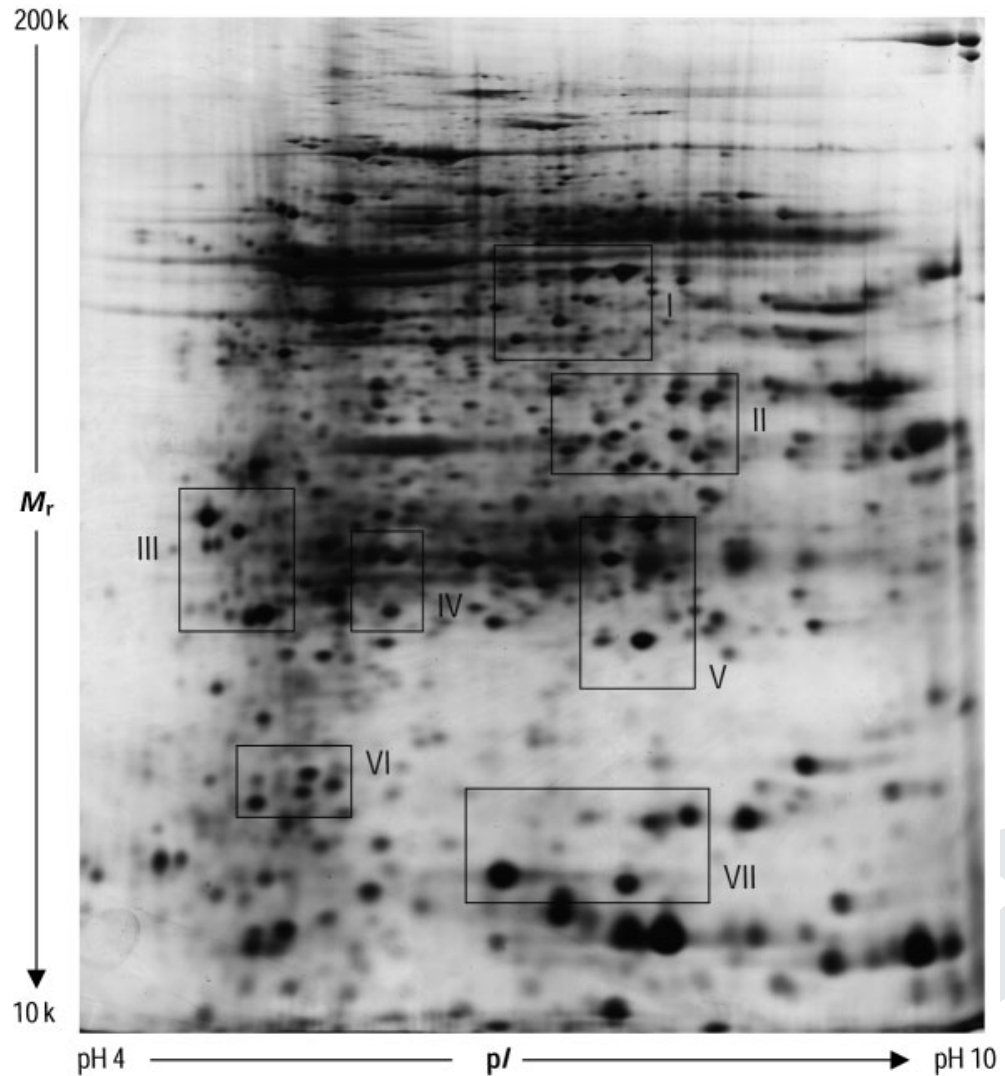

Figure 2. An overview of the master 2-D gel image for buccal SCC tissue. Highlighted in squares are the seven areas where significant and consistent differences were found in protein expression levels. gels with $M_{\mathrm{r}}$ lower than the matched full-length proteins. These three polypeptides are fragments of heat shock protein 70 (HSP70), gamma-actin and cytokeratin 6B, respectively. The protein identification of these three fragments was justified by the fact that the matched peptides are concentrated in certain parts of the protein sequences.

Only three proteins were identified to have similar trends of alteration in both tongue and buccal SCCs, with Cryst$B$ being down-regulated and HSP27 and mitochondrial ribosomal protein (MRP)-L13 being up-regulated in cancer tissues. It should be pointed out that the previously identified protein, nuclear FMRP interacting protein 1, in tongue SCC [4] is actually MRP-L13. This strongly overexpressed protein spot consistently appeared in both tongue and buccal tissues (Fig. 2, Area VII), but MS fingerprinting with trypsin-digested peptides did not produce a satisfactory match with low sequence coverage and MOWSE score [4]. Moreover, FMRP binding protein is not involved in tumorigenesis [4]. We therefore used chymotrypsin instead of trypsin in the in-gel digestion! $\square$ The resulting MS peptide fingerprint was satisfactorily matched to protein MRP-L13 (Table 2). Figures 3-6 display the detailed protein alterations between SCC and matched normal tissues. Compared to those in normal tissue, all identified proteins, except Cryst-B, were found to be significantly increased (+1.5-9.1-fold) in SCC tissue, while Cryst-B was dramatically decreased (-12.3fold) in cancer tissue. These over-expressed proteins can be classified into several categories based on their functions, including glycolytic enzymes, HSPs, detoxification and anti-oxidation proteins, cytoskeleton proteins, proteins involved in mitochondrial and intracellular signaling pathways, and tumor antigens. Table 3 summarizes the proteins and their functions, corresponding areas in the 2-D gel, and fold differences in buccal SCC compared to the control.

Among the proteins identified, enolase, annexin A2 and stratifin were found to have isoforms or cleaved polypeptides. While enolase had an isoform pattern (Fig. 3) similar to that previously seen in other tissues, annexin A2 and stratifin presented unique profiles of isoforms in buccal cancer tissue (Figs. 6 and 7). As indicated in Fig. 6, four spots, all elevated in cancer, were identified as stratifin, with the two spots in the lower $M_{\mathrm{r}}$ region being $C$-terminal truncated peptides as evidenced by MS fingerprinting sequencing. Detailed analysis of the MS spectra of tryptic peptides with possible modifications found that lysines at positions 68 and 77 can be methylated and threonine at position 165 can be phosphorylated, accounting for the 
Table 2. Results of MALDI-TOF mass spectra and database searching for protein identification

\begin{tabular}{|c|c|c|c|c|c|}
\hline Protein ID $\left(M_{\mathrm{r}} / \mathrm{p} /\right)$ & $\begin{array}{l}\text { Peptides } \\
\text { matched }\end{array}$ & $\begin{array}{l}\text { Sequence co- } \\
\text { verage }(\%)\end{array}$ & $\begin{array}{l}\text { Total mass } \\
\text { accuracy } \\
\text { (PPM) }\end{array}$ & $\begin{array}{l}\text { MOWSE } \\
\text { score }\end{array}$ & $\begin{array}{l}\mathrm{ACC} \# \\
(\mathrm{NCBI})\end{array}$ \\
\hline Phosphoglycerate mutase (PM), (29 kD/6.7) & $6-11$ & $28-42$ & 18 & 80990-94690 & 4505753 \\
\hline Enolase 1, (47 kD/7.0) & $27-34$ & $55-64$ & $21-22$ & 21280000 & 4503571 \\
\hline Pyruvate kinase (PK), (58 kD/8.0) & 13 & 26 & 23 & 86660 & 478822M \\
\hline Triosephosphate isomerase 1 (TPI), (27 kD/6.4) & 11 & 37 & 19 & 1344 & 4507645 \\
\hline $\begin{array}{l}\text { Glyceraldehyde-3-phosphate dehydrogenase } \\
\text { (GPDH), (36 kD/8.6) }\end{array}$ & 8 & 20 & 20 & 378 & 7669492 \\
\hline $\begin{array}{l}\text { Squamous cell carcinoma antigen (SCC-A), } \\
\quad(45 \mathrm{kD} / 6.3)\end{array}$ & $14-34$ & $31-54$ & $19-20$ & $\begin{array}{l}47310- \\
59720000\end{array}$ & 25005272 \\
\hline $\begin{array}{l}\text { Guanine nucleotide binding protein (GNBP), } \\
\text { (35 kD/7.6) }\end{array}$ & $8-9$ & $25-26$ & $15-17$ & $2192-4487$ & 5174447 \\
\hline Crystallin, alpha B (Cryst-B), (29 kD/6.8) & 14 & 52 & 24 & 58410 & 4503057 \\
\hline Heat shock 27 kD protein (HSP27), (23 kD/6.0) & $8-13$ & $42-47$ & $17-19$ & 2148-35160 & 15928913 \\
\hline $\begin{array}{l}\text { Heat shock } 70 \text { protein (HSP70) (fragment), } \\
\quad(71 \mathrm{kD} / 5.4)\end{array}$ & 11 & 17 & 11 & 23060 & 5729877 \\
\hline Aldo-keto reductase (AKR), (36 kD/7.7) & 5 & 14 & 17 & 280 & 3493209 \\
\hline Glutathione S-transferase (GST), (23 kD/5.4) & 7 & 43 & 8 & 2447 & 4504183 \\
\hline Annexin A1 (39 kD/6.6) & 12 & 38 & 18 & 164500 & 4502101 \\
\hline Annexin A2 (39 kD/7.6) & $8-38$ & $20-66$ & $12-22$ & 402-2071000 & 4757756 \\
\hline Annexin A5 (36 kD/4.9) & 8 & 23 & 18 & 6602 & 17391477 \\
\hline $\begin{array}{l}\text { Manganese superoxide dismutase (MnSOD), } \\
\qquad(23 \mathrm{kD} / 6.9)\end{array}$ & 7 & 30 & 16 & 1170 & 30841305 \\
\hline $\begin{array}{l}\text { Voltage-dependent anion channel } 2 \text { (VDAC2), } \\
\text { (30 kD/6.8) }\end{array}$ & 5 & 20 & 17 & 1160 & 15277577 \\
\hline $\begin{array}{l}\text { Mitochondrial ribosomal protein L13 (MRP-L13), } \\
(21 \mathrm{kD} / 9.2)\end{array}$ & 6 & 18 & 17 & 3090 & 1465270 \\
\hline Cyclophilin A (CyP-A), (18 kD/7.7) & 7 & 17 & 13 & 275 & 6679439 \\
\hline Stratifin (14-3-3 sigma), (28 kD/4.7) & $10-14$ & $45-52$ & $11-16$ & $314-10060$ & 5454052 \\
\hline Galectin 7, (15 kD/7.0) & 21 & 83 & 16 & 1998 & 4504985 \\
\hline Actin, gamma (fragment), (42 kD/5.3) & 4 & 11 & 25 & 216 & $71625 \mathrm{M}$ \\
\hline Cytokeratin 6B (CK-6B) (fragment), (60 kD/8.1) & 7 & 13 & 26 & 89 & 5031841 \\
\hline
\end{tabular}

multiple spots of stratifin observed in the gel. 2-D Western blotting images showing the isoform patterns of annexin A2 in normal and SCC tissues are shown in Fig. 7. Annexin A2 was obviously cleaved into different polypeptides. Over-expression was detected in all species except one low $M_{\mathrm{r}}$ fragment of the protein. Phosphorylated modification was also possible in some of the high $M_{\mathrm{r}}$ species. Detailed MS spectral analysis showed that phosphorylation can occur at Thr 44, Thr 48, Ser 294 and Ser 296, leading to isoforms with a roughly 0.2 difference in $\mathrm{p} /$.

\section{Discussion}

\subsection{Aberrant cell growth in buccal SCC}

The buccal mucosa is the most common site of oral SCC. Malignant transformation of the buccal mucosa starts in the squamous epithelium, the site susceptible to the stimuli of lime chewing and smoking. The normal squamous epithelium needs to maintain a balance between cell proliferation and cell death. The aggressive cell proliferation or tumor formation is generally due to impaired cell apoptosis. The substantial over-expression of SCC antigen in 

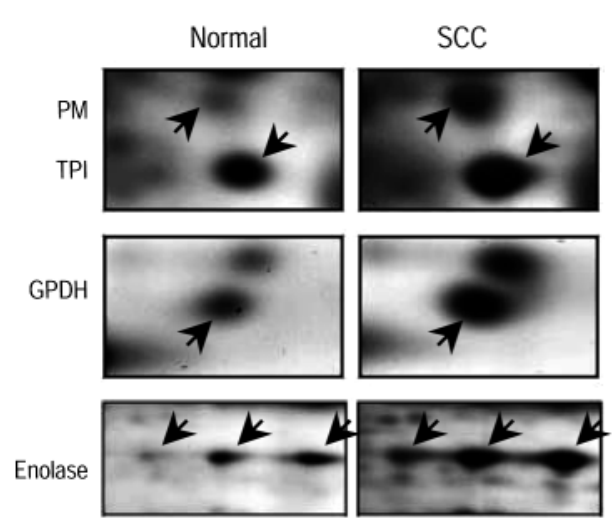

PK
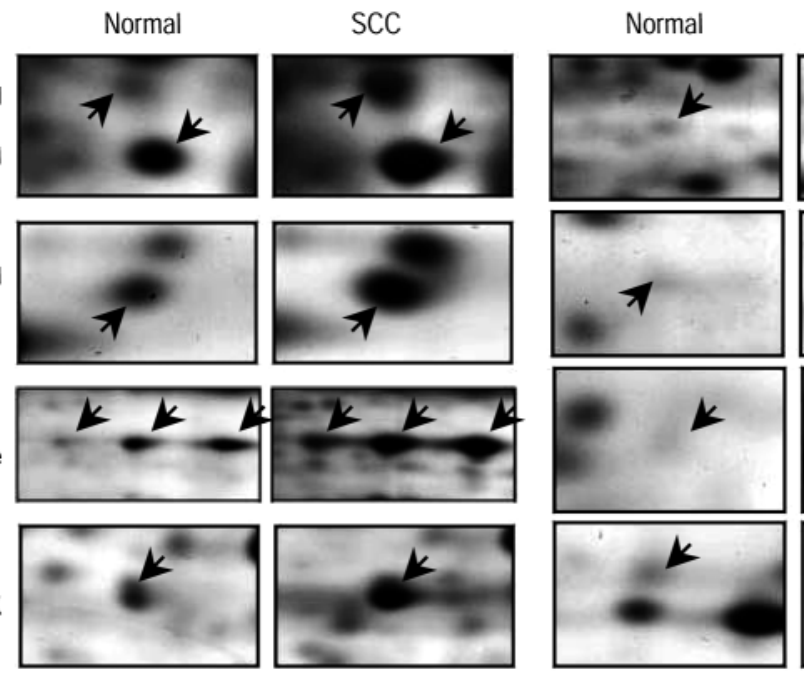

Normal
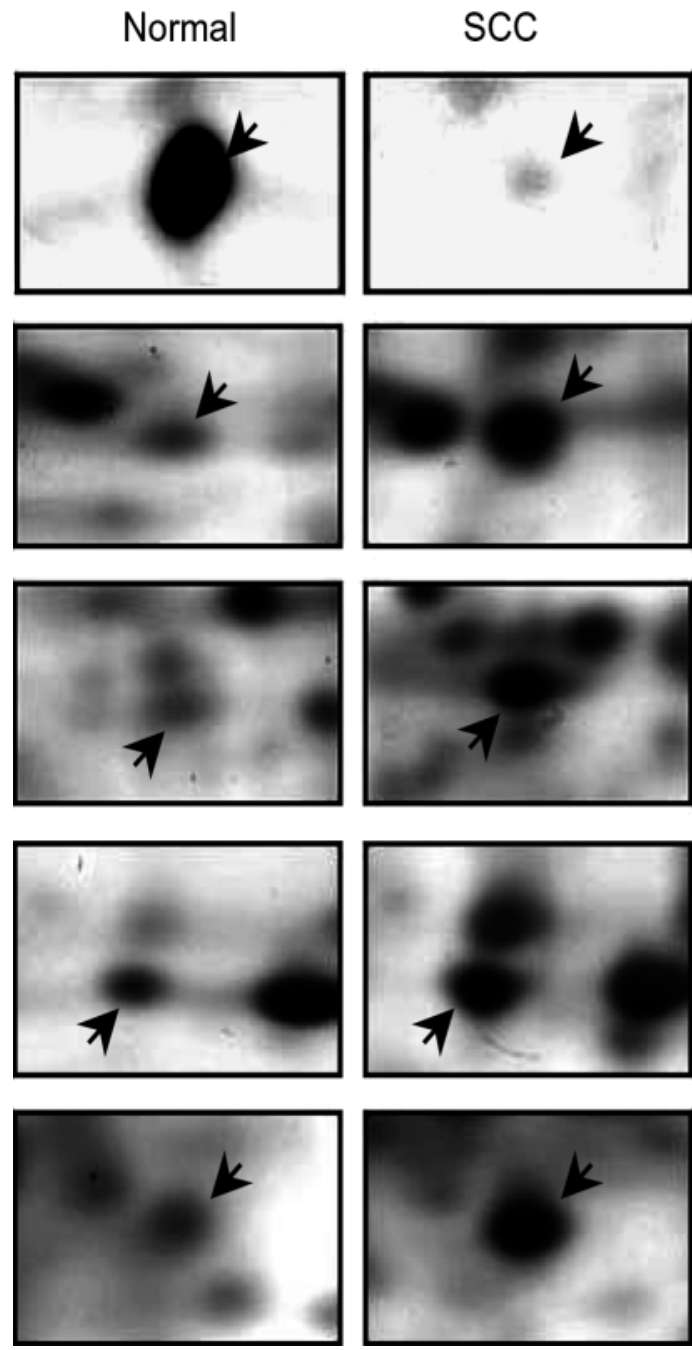

Cryst-B

HSP27

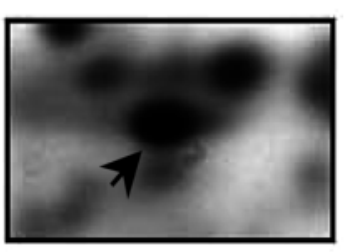

HSP70

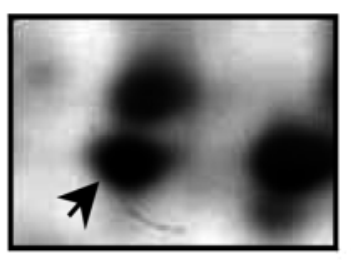

AKR

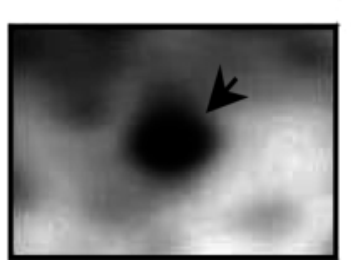

GST

Figure 4. Detailed alteration patterns of proteins: crystalline alpha B (Cryst-B), HSP27, HSP70, aldo-keto reductase (AKR), and glutathione $S$-transferase (GST).
SCC

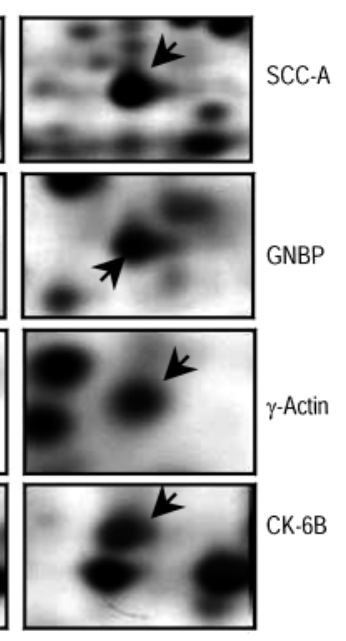

Figure 3. Detailed alteration patterns of proteins: phosphoglycerate mutase (PM), triosephosphate isomerase (TPI), glyceraldehydes-3-phosphate dehydrogenase (GPDH), enolase, pyruvate kinase $(\mathrm{PK})$, squamous cell carcinoma antigen (SCC-A), guanine nucleotide binding protein (GNBP), gamma actin and cytokeratin 6B (CK-6B). the present buccal SCC is the first of apoptotic imbalance. SCC antigen, a member of the serine proteinase inhibitor family, inhibits apoptosis and migration of natural killer cells by interacting with target proteinases [6-9]. Although it is also expressed in the intermediate layer of the normal squamous epithelium, the SCC antigen was found to be highly up-regulated in various SCC cancers, including those in the uterine cervix, lung, esophagus, head, neck, and skin $[8,10]$. Our current observation reinforces the characteristic of SCC-antigen as a specific tumor marker for SCC. Another sign of the aberrant cell proliferation in buccal SCC is the increased energy requirement for cell differentiation, indicated by the upregulation of five glycolytic enzymes (phosphoglycerate mutase, enolase, pyruvate kinase TPI and glyceraldehydes-3-phosphate dehydrogenase). Glycolysis is an energy generation pathway, active in all differentiated cell types in multicellular organisms. Elevated expression and activities of glycolytic enzymes have been detected in various malignant tumors such as lung, colon, liver and breast carcinomas [11-13].

A significant increase in guanine nucleotide binding protein (GNBP) is also detected during malignant cell transformation in buccal SCC. GNBP, also called G proteins, belong to the Ras superfamily which consists of the Ras, Rho, and Arf families. The protein members of this family are widely involved in human tumorigenesis, either through activating mutations or by over-expression to induce cell transformation [14, 15]. It has been shown that oncogenic mutations of Ras proteins, through farnesyl protein transferase-catalyzed farnesylation, are prevalent in many human cancers [15], indicating that G proteins are potential drug targets in cancer therapy where Ras farnesylation can be blocked by introducing inhibitors of farnesyl protein transferase [15].

www.proteomics-journal.de 
Table 3. Summary of altered proteins and their cellular functions, corresponding areas in the 2-D gel and volume differences (average values of triplicate measurements) in buccal SCC

\begin{tabular}{|c|c|c|c|}
\hline Protein ID $\left(M_{\mathrm{r}} / \mathrm{p} /\right)$ & Area & Function & $\begin{array}{l}\text { Change } \\
\text { (fold) }\end{array}$ \\
\hline Phosphoglycerate mutase (PM), (29 kD/6.7) & V & Glycolysis, energy generation & +3 \\
\hline Enolase 1, (47 kD/7.0) & I & Glycolysis, energy generation & +2.3 \\
\hline Pyruvate kinase (PK), (58 kD/8.0) & I & Glycolysis, energy generation & +3.3 \\
\hline Triosephosphate isomerase 1 (TPI), (27 kD/6.4) & $\mathrm{V}$ & Glycolysis, energy generation & +1.6 \\
\hline $\begin{array}{l}\text { Glyceraldehyde-3-phosphate dehydrogenase } \\
\text { (GPDH), (36 kD/8.6) }\end{array}$ & II & Glycolysis, energy generation & +2.6 \\
\hline $\begin{array}{l}\text { Squamous cell carcinoma antigen (SCC-A), } \\
(45 \mathrm{kD} / 6.3)\end{array}$ & I & $\begin{array}{l}\text { Inhibits apoptosis and migration of natural } \\
\text { killer cells }\end{array}$ & +4.2 \\
\hline $\begin{array}{l}\text { Guanine nucleotide binding protein (GNBP), } \\
(35 \mathrm{kD} / 7.6)\end{array}$ & II & Induces cell transformation through mutations & +4.7 \\
\hline Crystallin, alpha B (Cryst-B), (29 kD/6.8) & V & Stress protein, chaperone, protection & -12.3 \\
\hline Heat shock 27 kD protein (HSP27), (23 kD/6.0) & IV & Stress protein, chaperone, protection & +2 \\
\hline $\begin{array}{l}\text { Heat shock } 70 \text { protein (HSP70) (fragment), } \\
(71 \mathrm{kD} / 5.4)\end{array}$ & ॥ & Stress protein, chaperone, protection & +2 \\
\hline Aldo-keto reductase (AKR), (36 kD/7.7) & ॥ & $\begin{array}{l}\text { Cytosolic enzyme in cellular detoxification } \\
\text { and protection }\end{array}$ & +2.5 \\
\hline Glutathione S-transferase (GST), (23 kD/5.4) & IV & $\begin{array}{l}\text { Cytosolic enzyme in cellular detoxification } \\
\text { and protection }\end{array}$ & +2.2 \\
\hline Annexin A1 (39 kD/6.6) & ॥ & $\begin{array}{l}\mathrm{Ca}^{+} \text {channels, combats inflammation, } \\
\text { suppress tumors }\end{array}$ & +2.3 \\
\hline Annexin A2 (39 kD/7.6) & ॥ & $\begin{array}{l}\mathrm{Ca}^{+} \text {channels, combats inflammation, } \\
\text { suppress tumors }\end{array}$ & +4.8 \\
\hline Annexin A5 (36 kD/4.9) & III & $\begin{array}{l}\mathrm{Ca}^{+} \text {channels, combats inflammation, } \\
\text { suppress tumors }\end{array}$ & +1.5 \\
\hline $\begin{array}{l}\text { Manganese superoxide dismutase (MnSOD), } \\
(23 \mathrm{kD} / 6.9)\end{array}$ & V & $\begin{array}{l}\text { Anti-oxidant enzyme with tumor suppressor } \\
\text { activity, modulates mitochondrial signaling, } \\
\text { reduces mitochondrial damage }\end{array}$ & +2.1 \\
\hline $\begin{array}{l}\text { Voltage-dependent anion channel } 2 \text { (VDAC2), } \\
\qquad(30 \mathrm{kD} / 6.8)\end{array}$ & ॥ & $\begin{array}{l}\text { Regulates apoptosis, a death signal-convergence } \\
\text { point }\end{array}$ & +5.1 \\
\hline $\begin{array}{l}\text { Mitochondrial ribosomal protein L13 (MRP-L13), } \\
(21 \mathrm{kD} / 9.2)\end{array}$ & VII & $\begin{array}{l}\text { Biosynthesis of mitochondrial proteins, } \\
\text { mitochondrial signaling. }\end{array}$ & +3.1 \\
\hline Cyclophilin A (CyP-A), (18 kD/7.7) & VII & $\begin{array}{l}\text { Involves intracellular signal transduction, } \\
\text { regulates pathways of T cell stimulation, } \\
\text { secreted by cells in response to inflammatory } \\
\text { stimuli. }\end{array}$ & +2.3 \\
\hline Stratifin (14-3-3 sigma), (28 kD/4.7) & III & $\begin{array}{l}\text { Chaperone, regulates signaling pathway, } \\
\text { tumor suppressor gene }\end{array}$ & $\begin{array}{c}+2.8- \\
9.1\end{array}$ \\
\hline Galectin 7, 15 kD/7.0) & VII & $\begin{array}{l}\text { Promotes apoptosis, functions through } \\
\text { JNK pathway }\end{array}$ & +4.1 \\
\hline Actin, gamma (fragment), (42 kD/5.3) & $\mathrm{VI}$ & Cytoskelaten protein, involves cell proliferation & +7.0 \\
\hline Cytokeratin 6B (CK-6B) (fragment), (60 kD/8.1) & II & Cytoskelaten protein, involves cell proliferation & +4.8 \\
\hline
\end{tabular}

\subsection{Self defense in buccal SCC}

Cells contain a number of antioxidant, antitoxic and antiinflammatory defenses $[16,17]$. Aberrant increases in the levels of proteins related to stress, detoxification, and anti-oxidation in buccal SCC imply the stimulation of cell defense systems in response to malignant transformation. HSPs are well-known antistress proteins. HSP over-expression usually correlates with harmful insults to the cell [18]. HSPs may offer a protective advantage 


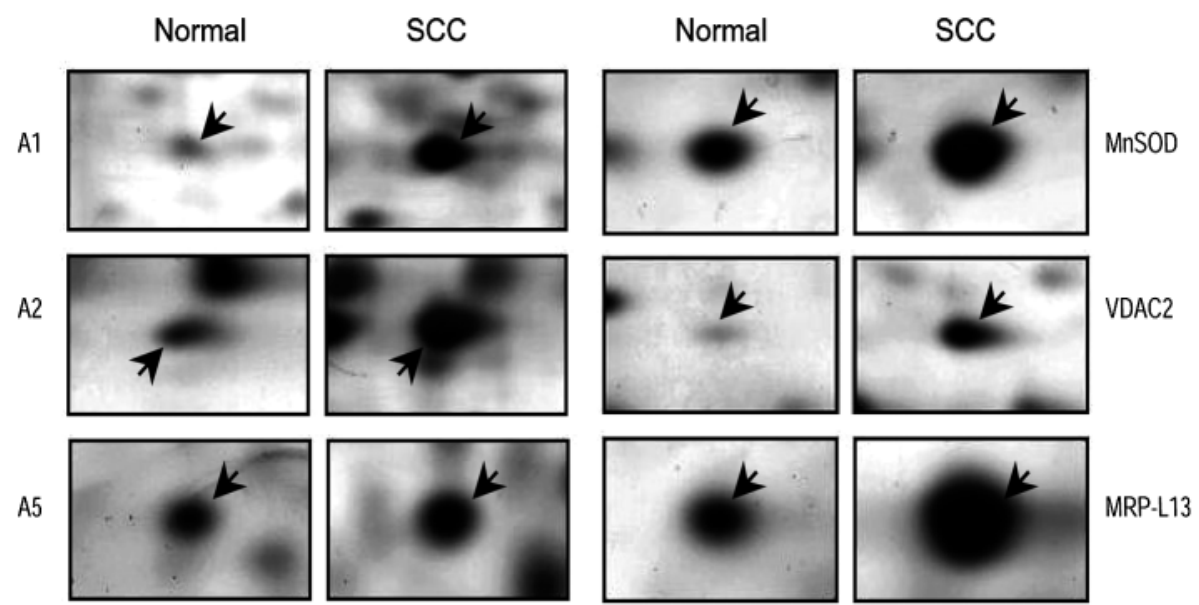

Figure 5. Detailed alteration patterns of proteins: annexin A1, A2 and A5, MnSOD, VDAC2, and MRP-L13.

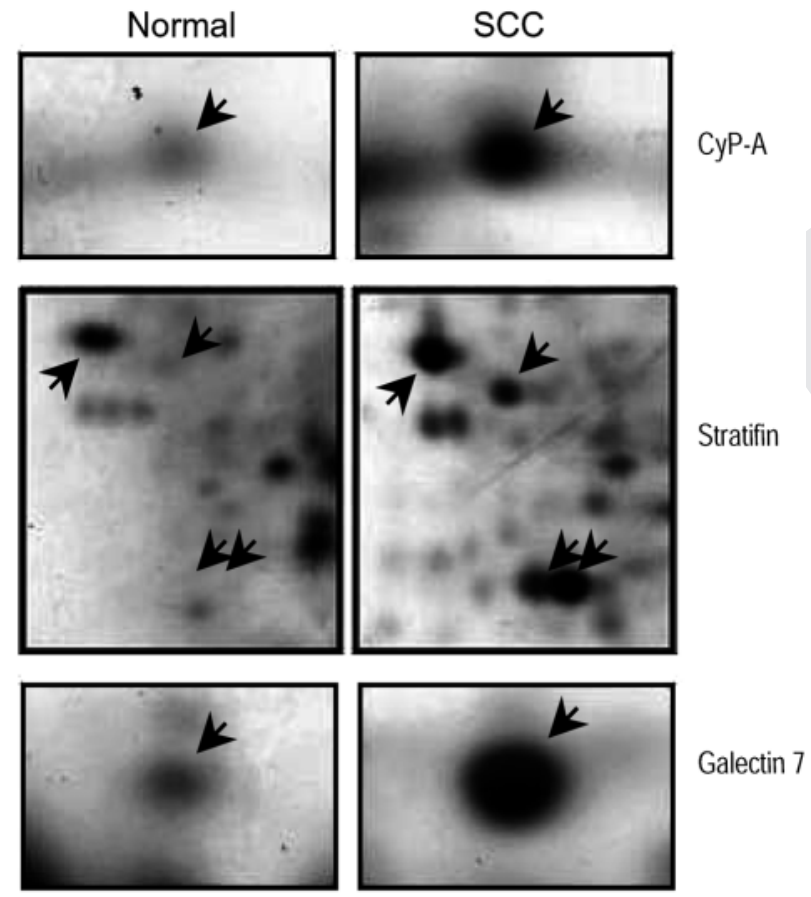

Figure 6. Detailed alteration patterns of proteins: cyclophilin A (CyP-A), stratifin and galectin 7 . through their functions as molecular chaperones. In vitro experiments have also demonstrated that HSP27 and HSP70 protected mitochondria against injury by inhibiting cytochrome c-mediated procaspase 9 processing $[19,20]$. In contrast, Cryst-B often displays a different behavior in response to stress. Cryst-B has been shown to negatively regulate cytochrome c- and caspase-8dependent activation of caspase-3 [21]. Reduced expression of Cryst-B has been found in various tumors $[4,22,23]$. The dramatic suppression of Cryst-B expression observed in the buccal SCC once again reflects the distinctive role the protein plays which is different from HSPs in the process of carcinogenesis. GST and aldoketo reductase (AKR) belong to two main cytosolic enzyme families involved in the detoxification processes. GSTs catalyze the glutathione conjugation reaction with eletrophilic compounds and carcinogens [24], while AKRs catalyze the NADPH-dependent reduction of a large variety of xenobiotic and endogenous toxic compounds $[25,26]$. $\mathbf{D}$ please check sentence $\mathbf{T}$ The upregulation of GST and AKR in buccal cancer corresponds to the activation of self-protective mechanisms in cells involved in the tumorigenetic processes. Overexpression of GSTs and AKRs have also been detected
Normal

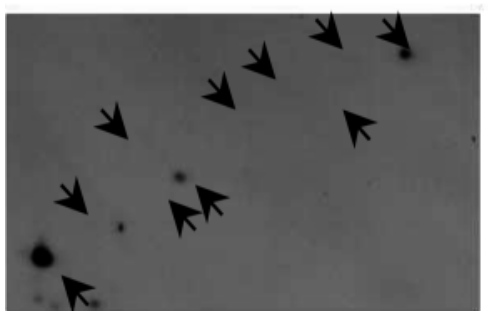

SCC

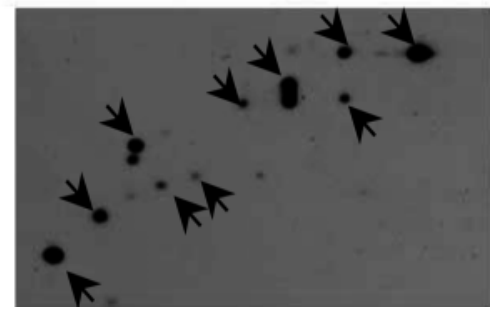

Figure 7. 2-D Western blotting patterns showing the different expression of annexin A2 and its isoforms and cleaved fragments in normal and SCC tissues. 
in other oral SCCs [27-29] and carcinomas [30-32]. These proteins may therefore serve as potential tumor markers and drug targets.

The elevation of manganese superoxide dismutase (MnSOD) implies that the well-known antioxidant defense system has been stimulated. Numerous studies have suggested that MnSOD protects cells from injury and suppresses tumor growth [33-35]. Over-expression of MnSOD has even been tested as an anti-oral SCC therapy [36-38]. Up-regulation of annexin A1, A2 and A5 is another indicator of cell's effort to protect itself. Annexins are water soluble proteins that function as $\mathrm{Ca}^{2+}$ channels and regulate membrane fusion, a process underlying organelle biogenesis and cell division [39]. Although its physiological function in vivo is largely unknown, in vitro annexins exhibited anti-inflammatory $[39,40]$ and tumor suppression activities $[40,41]$. Several recent proteomic studies identified significant over-expressed of annexin A5 in head, neck and skin SCC tumors [42, 43], indicating that it may be a specific SCC biomarker. In contrast annexin $A 1$ and $A 2$ were found to have reduced expressions in prostate $[44,45]$ and esophageal carcinomas [46, 47] but were up-regulated in head and neck SCC cells [48]. These findings and our present observations suggest that over-expression of annexin $A 1, A 2$ and $A 5$ is a phenomenon specific to oral SCC.

\subsection{Mitochondrial-mediated apoptosis}

The remarkable elevation in the expression of three mitochondrial proteins (voltage-dependent anion channel VDAC) 2, MnSOD and MRP-L13) reflects the involvement of mitochondrial mediated apoptosis in buccal carcinogenesis. Recent studies on apoptosis signaling cascades have revealed that mitochondria play a central role in regulating apoptosis [49-52]. The release of cytochrome c and other proapoptotic proteins from mitochondria is an important hallmark for apoptosis initiation. The release of cytochrome $\mathrm{c}$ and proapoptotic protein takes place through VDACs on the outer membranes of mitochondria, signaling the activation of death-promoting proteolytic enzymes known as caspases, which induce apoptosis. -.. please rewrite sentence $\mathbf{U}$ VACs serve as a death signal-convergence point to facilitate the release of cytochrome $\mathrm{c}$ and initiation of apoptosis by increasing expression levels. Mitochondrial VDACs have therefore been proposed as therapeutic targets for triggering cell death and thus suppressing tumor growth [53].

As stated above, MnSOD can protect cells from injury. This protection effect originates from the ability of MnSOD to convert reactive oxygen species (ROS) which have been implicated in signal transduction and carcinogenesis. In cells, the mitochondrial respiratory chain is the major site for ROS production $[54,55]$ and MnSOD is the major enzyme in mitochondria responsible for decomposition of ROS $[56,57]$. Mitochondrial ROS play an important role in apoptosis because they can readily influence mitochondrial function without having to diffuse a long way from the cytosol $[58,59]$. It has been shown that MnSOD overexpression alters the redox environment in mitochondria and the metabolic capacity of the cell, leading to inhibition of cell growth [60]. MRPs, together with two RNA molecules, comprise the mitochondrial translation machinery for the biosynthesis of proteins encoded by mitochondrial DNA. The observed increases in mitochondrial proteins may therefore be closely related to over-expression of MRPs. Increasing data have demonstrated that MRPs are also involved in apoptosis induction [61-63] and tumor suppression [63, 64]. One MRP, death-associated protein 3 , is actually a proapoptotic protein released from mitochondria [62], implying the direct involvement of MRPs in mitochondrial mediated apoptosis.

\subsection{Intracellular signaling pathways}

The substantial up-regulation of the proteins cyclophilin A (CyP-A), stratifin and galectin 7 provides evidence for the involvement of intracellular signaling pathways in buccal tumorigenesis. CyP-A is a member of the family of immunophilin proteins, extensively studied for their role in cellular signaling pathways $[65,66]$. By forming complexes with various immunosuppressive drugs, notably Cyclosporin A, CyP-A inhibits T-cell receptor-mediated signal transduction and thus regulates $T$ cell activation $[65,67,68]$. CyP-A has also been shown to possess chaperone characteristics: it is secreted by cells in response to inflammatory stimuli and can modulate protein folding $[66,69]$. The numerous activities that CyP-A exerts in cellular growth and differentiation, transcriptional control and cell signaling suggests that it may play a unique role in an important aspect of oncogenesis. CyP-A over-expression has recently been detected in nonsmall cell lung cancer [70] and hepatocellular carcinoma [71].

Stratifin, also a molecular chaperone, is known as tumor suppressor protein 14-3-3 sigma. It plays significant roles in a number of cellular activities, such as cell cycle progression, growth, differentiation and apoptosis, by regulating various cytoplasm signaling pathways. Stratifin is a negative cell cycle regulator that reduces cell growth by causing G2 arrest [72, 73]. This activity, together with its absence in breast cancer, suggests that it contributes to breast tumor growth [72, 74]. In addition, decreased expression of stratifin was found in neuroendocrine lung tumors [75] and in bladder SCC [76]. However, a recent 
study revealed that stratifin is expressed at high levels in several skin diseases including SCC [77]. We also observed this unexpected phenomenon in the present study with buccal SCC: strong stratifin over-expression was observed for the intact molecule as well as all phospharylated and truncated forms of stratifin. The pathological meanings of the different expressions of stratifin in different cancers may be an intriguing subject for further investigations. Galectin 7 is another apoptosis regulator that functions intracellularly through the JNK signaling pathway to influence cell growth and differentiation [78, 79]. Similar to its family member galectin 1 , galectin 7 may also possess dual characteristics associated with pro- and anti-tumoral activities at different stages of tumor progression [80]. This explains why the expression level of galectin 7 was significantly increased in chemically induced mammary carcinogenesis [81] but markedly decreased in thyroid lesions of adenomas [80]. Reconciled with the elevated expression of galectin 7 in well-differentiated bladder SCC [76] and lymphoma [82], the strong up-regulation of the protein in this study may reflect the aggressiveness of buccal SCC.

\section{Concluding remarks}

Our current findings clearly demonstrated that multiple pathways and systems are involved in SCC tumorigenesis. Both tumor antigens and tumor suppressor proteins participate in the process of carcinogenesis, indicating that cell defenses are initiated to fight malignant transformation. Global analyses of variations in protein expression in this study suggest that an imbalance between apoptosis and cell proliferation may be a pathological reason for buccal SCC. A combinational strategy which simultaneously targets different pathways may be an effective remedy to counter this disease. Candidates proteins for targeting include SCC antigen, GNBP, GST, MnSOD, annexins, VDAC, CyP-A, stratifin and galectin 7 . Although no specific biomarker for buccal SCC was found in this study, the current success in identifying a number of tumor-associated proteins proved that proteomic analysis can provide rich information to help understand the pathology of a disease in an integrated way. This type of information should lead to more rationally designed diagnostic and treatment methods, which will hopefully translate into improved patient outcome.

This work was supported by grants from the Hong Kong Research Grants Council (HKU 7227/02M to Q.Y.H., HKU 7218/02M and HKU 7395/03M to J.F.C.), the Department of Chemistry, and the Areas of Excellence scheme from the Hong Kong University Grants Committee. We thank Ms. Yuan Zhou for technical assistance.

\section{References}

[1] Diaz, E. M., Jr., Holsinger, F. C., Zuniga, E. R., Roberts, D. B. et al. , Head Neck 2003, 25, 267-273.

[2] Ko, Y. C., Huang, Y. L., Lee, C. H., Chen, M. J. et al., J. Oral Pathol. Med. 1995, 24, 450-453.

[3] Chen, Y. K., Huang, H. C., Lin, L. M., Lin, C. C., Oral Oncol. 1999, 35, 173-179.

[4] He, Q. Y., Chen, J., Kung, H. F., Yuen, A. P. et al., Proteomics 2004, 4, 271-278.

[5] He, Q. Y., Lau, G. K., Zhou, Y., Yuen, S. T. et al., Proteomics 2003, 3, 666-674.

[6] Suminami, Y., Nagashima, S., Murakami, A., Nawata, S. et al., Cancer Res. 2001, 61, 1776-1780.

[7] Suminami, Y., Nagashima, S., Vujanovic, N. L., Hirabayashi, K. et al., Br. J. Cancer 2000, 82, 981-989.

[8] Suminami, Y., Nawata, S., Kato, H., Tumour Biol. 1998, 19, 488-493.

[9] Murakami, A., Suminami, Y., Hirakawa, H., Nawata, S. et al., Br. J. Cancer 2001, 84, 851-858.

[10] Torre, G. C., Tumour Biol. 1998, 19, 517-526.

[11] Durany, N., Joseph, J., Jimenez, O. M., Climent, F. et al., Br. J. Cancer 2000, 82, 20-27.

[12] Durany, N., Joseph, J., Campo, E., Molina, R. et al., Br. J. Cancer 1997, 75, 969-977.

[13] Usuba, T., Ishibashi, Y., Okawa, Y., Hirakawa, T. et al., Int. J. Cancer 2001, 94, 662-668.

[14] Oxford, G., Theodorescu, D., Cancer Lett. 2003, 189, 117128.

[15] Midgley, R. S., Kerr, D. J., Crit. Rev. Oncol. Hematol. 2002, 44, 109-120.

[16] Mates, J. M., Sanchez-Jimenez, F., Front. Biosci. 1999, 4, D339-D345.

[17] Cerutti, P. A., Trump, B. F., Cancer Cells 1991, 3, 1-7.

[18] Kiang, J. G., Tsokos, G. C., Pharmacol. Ther. 1998, 80, 183201.

[19] Mosser, D. D., Caron, A. W., Bourget, L., Meriin, A. B. et al., Mol. Cell Biol. 2000, 20, 7146-7159.

[20] Bruey, J. M., Ducasse, C., Bonniaud, P., Ravagnan, L. et al., Nat. Cell Biol. 2000, 2, 645-652.

[21] Kamradt, M. C., Chen, F., Cryns, V. L., J. Biol. Chem. 2001, 276, 16059-16063.

[22] Takashi, M., Katsuno, S., Sakata, T., Ohshima, S. et al., Urol. Res. 1998, 26, 395-399.

[23] Kato, K., Ito, H., Hasegawa, K., Inaguma, Y. et al., J. Neurochem. 1996, 66, 946-950.

[24] Tsuchida, S., Sato, K., Crit. Rev. Biochem. Mol. Biol. 1992, 27, 337-384.

[25] Ellis, E. M., FEMS Microbiol. Lett. 2002, 216, 123-131.

[26] Jez, J. M., Bennett, M. J., Schlegel, B. P., Lewis, M. et al., Biochem. J. 1997, 326, 625-636.

[27] Lafuente, A., Maristany, M., Arias, C., Cuchi, A. et al., Anticancer Res. 1998, 18, 107-111.

[28] Li, T. J., Hirayama, Y., Kitano, M., Virchows Arch. 1997, 431, 37-43.

[29] Zhang, L., Xiao, Y., Priddy, R., J. Oral Pathol. Med. 1994, 23, 75-79.

[30] Palackal, N. T., Lee, S. H., Harvey, R. G., Blair, I. A. et al., J. Biol. Chem. 2002, 277, 24799-24808.

[31] Scuric, Z., Stain, S. C., Anderson, W. F., Hwang, J. J., Hepatology 1998, 27, 943-950.

[32] Takahashi, M., Fujii, J., Miyoshi, E., Hoshi, A. et al., Int. J. Cancer 1995, 62, 749-754. 
[33] Weydert, C., Roling, B., Liu, J., Hinkhouse, M. M. et al., Mol. Cancer Ther. 2003, 2, 361-369.

[34] Cullen, J. J., Weydert, C., Hinkhouse, M. M., Ritchie, J. et al., Cancer Res. 2003, 63, 1297-1303.

[35] Zhao, Y., Xue, Y., Oberley, T. D., Kiningham, K. K. et al., Cancer Res. 2001, 61, 6082-6088.

[36] Darby Weydert, C. J., Smith, B. B., Xu, L., Kregel, K. C. et al., Free Radical Biol. Med. 2003, 34, 316-329.

[37] Oberley, L. W., Antioxid. Redox Signal. 2001, 3, 461-472.

[38] Liu, R., Oberley, T. D., Oberley, L. W., Hum. Gene Ther. 1997, 8, 585-595.

[39] Kourie, J. I., Wood, H. B., Prog. Biophys. Mol. Biol. 2000, 73, 91-134.

[40] Benz, J., Hofmann, A., Biol. Chem. 1997, 378, 177-183.

[41] Bastian, B. C., Cell. Mol. Life Sci. 1997, 53, 554-556.

[42] Melle, C., Ernst, G., Schimmel, B., Bleul, A. et al., Mol. Cell Proteomics 2003, 2, 443-452.

[43] Dooley, T. P., Reddy, S. P., Wilborn, T. W., Davis, R. L., Biochem. Biophys. Res. Commun. 2003, 306, 1026-1036.

[44] Liu, J. W., Shen, J. J., Tanzillo-Swarts, A., Bhatia, B. et al., Oncogene 2003, 22, 1475-1485.

[45] Kang, J. S., Calvo, B. F., Maygarden, S. J., Caskey, L. S. et al., Clin. Cancer Res. 2002, 8, 117-123.

[46] Xia, S. H., Hu, L. P., Hu, H., Ying, W. T. et al., Oncogene 2002, 21, 6641-6648.

[47] Zhou, G., Li, H., DeCamp, D., Chen, S. et al., Mol. Cell Proteomics 2002, 1, 117-124.

[48] Wu, W., Tang, X., Hu, W., Lotan, R. et al., Clin. Exp. Metastasis 2002, 19, 319-326.

[49] Tsujimoto, Y., Shimizu, S., Cell Death Differ. 2000, 7, 11741181.

[50] Gupta, S., Life Sci. 2001, 69, 2957-2964.

[51] Martinou, J. C., Green, D. R., Nat. Rev. Mol. Cell Biol. 2001, 2, 63-67.

[52] Zamzami, N., Kroemer, G., Nat. Rev. Mol. Cell Biol. 2001, 2, 67-71.

[53] Granville, D. J., Gottlieb, R. A., Curr. Med. Chem. 2003, 10, 1527-1533.

[54] Barja, G., J. Bioenerg. Biomembr. 1999, 31, 347-366.

[55] Boveris, A., Adv. Exp. Med. Biol. 1977, 78, 67-82.

[56] Boveris, A., Cadenas, E., FEBS Lett. 1975, 54, 311-314.

[57] Weisiger, R. A., Fridovich, I., J. Biol. Chem. 1973, 248, 35823592.

[58] Green, D. R., Reed, J. C., Science 1998, 281, 1309-1312.
[59] Tan, S., Sagara, Y., Liu, Y., Maher, P. et al., J. Cell Biol. 1998, 141, 1423-1432.

[60] Kim, K. H., Rodriguez, A. M., Carrico, P. M., Melendez, J. A., Antioxid. Redox Signal. 2001, 3, 361-373.

[61] Kissil, J. L., Cohen, O., Raveh, T., Kimchi, A., EMBO J. 1999, 18, 353-362.

[62] Cavdar, K. E., Ranasinghe, A., Burkhart, W., Blackburn, K. et al., FEBS Lett. 2001, 492, 166-170.

[63] Khanna, N., Sen, S., Sharma, H., Singh, N., Biochem. Biophys. Res. Commun. 2003, 304, 26-35.

[64] Marty, L., Taviaux, S., Fort, P., Genomics 1997, 41, 453-457.

[65] Schreiber, S. L., Science 1991, 251, 283-287.

[66] Yurchenko, V., Zybarth, G., O'Connor, M., Dai, W. W. et al., J. Biol. Chem. 2002, 277, 22959-22965.

[67] Bierer, B. E., Schreiber, S. L., Burakoff, S. J., Eur. J. Immunol. 1991, 21, 439-445.

[68] Hultsch, T., Albers, M. W., Schreiber, S. L., Hohman, R. J., Proc. Natl. Acad. Sci. USA 1991, 88, 6229-6233.

[69] Brazin, K. N., Mallis, R. J., Fulton, D. B., Andreotti, A. H., Proc. Natl. Acad. Sci. USA 2002, 99, 1899-1904.

[70] Campa, M. J., Wang, M. Z., Howard, B., Fitzgerald, M. C. et al., Cancer Res. 2003, 63, 1652-1656.

[71] Lim, S. O., Park, S. J., Kim, W., Park, S. G. et al., Biochem. Biophys. Res. Commun. 2002, 291, 1031-1037.

[72] Urano, T., Saito, T., Tsukui, T., Fujita, M. et al., Nature 2002, 417, 871-875.

[73] Hermeking, H., Lengauer, C., Polyak, K., He, T. C. et al., Mol. Cell 1997, 1, 3-11.

[74] Vercoutter-Edouart, A. S., Lemoine, J., Le, B., X., Louis, H. et al., Cancer Res. 2001, 61, 76-80.

[75] Yatabe, Y., Osada, H., Tatematsu, Y., Mitsudomi, T. et al., Oncogene 2002, 21, 8310-8319.

[76] Ostergaard, M., Rasmussen, H. H., Nielsen, H. V., Vorum, H. et al., Cancer Res. 1997, 57, 4111-4117.

[77] Lodygin, D., Yazdi, A. S., Sander, C. A., Herzinger, T. et al., Oncogene 2003, 22, 5519-5524.

[78] Yang, R. Y., Liu, F. T., Cell Mol. Life Sci. 2003, 60, 267-276.

[79] Kuwabara, I., Kuwabara, Y., Yang, R. Y., Schuler, M. et al., J. Biol. Chem. 2002, 277, 3487-3497.

[80] Rorive, S., Eddafali, B., Fernandez, S., Decaestecker, C. et al., Mod. Pathol. 2002, 15, 1294-1301.

[81] Lu, J., Pei, H., Kaeck, M., Thompson, H. J., Mol. Carcinog. 1997, 20, 204-215.

[82] Moisan, S., Demers, M., Mercier, J., Magnaldo, T. et al., Leukemia 2003, 17, 751-759. 